\title{
A spacial analysis of organic matter, oxides and granulometric distribution on sediments as a support for geochemical analysis on Três Marias reservoir - Minas Gerais
}

Gustavo Filemon Costa Lima ${ }^{1 *}$ Ciro Couto Bento ${ }^{2}$ Adolf Heinrich Horn ${ }^{1}$ Hernando Baggio Filho ${ }^{2}$

1 Department of Geology Institute of Geosciences Federal University of Minas Gerais Av. Antonio Carlos 6627 Belo Horizonte MG Brazil CEP 31270-901.

${ }^{2}$ Geology Center

Science and Technology Institute Federal University of Vale do Jequitinhonha and Mucuri. R. Cruzeiro, 1

Teófilo Otoni MG Brazil CEP 39803-371.

${ }^{*}$ Corresponding author: gustavo_filemon@yahoo.com.br

\section{RESUMO}

Esta investigação avalia a disposição da matéria orgânica, dos óxidos de ferro e alumínio, bem como a distribuição granulométrica nos sedimentos de fundo na represa de Três Marias/MG. Foi realizada a coleta de 40 amostras ao longo de todo o lago. O material coletado foi aquecido em estufa a $40^{\circ} \mathrm{C}$ por 36 horas e, em seguida, submetido ao peneiramento. As concentrações de ferro e alumínio foram determinadas por ICP OES. O teor de matéria orgânica foi obtido pelo método de perda por ignição. Os resultados foram confrontados com os valores preconizados pela a norma de qualidade guia de sedimentos - CONAMA No. 354/2012. Em 7 amostras o conteúdo em matéria orgânica está acima do limite legal. $O$ aporte sedimentar proveniente dos tributários São Francisco, São Vicente, Paraopeba, Extrema, Ribeirão do Boi, Borrachudo e Indaiá mostra uma geral predominância da deposição de partículas tamanho areia e uma ampla disparidade na granulometria entre seus sedimentos de fundo. As maiores concentrações de alumínio foram observadas na porção centro-leste da represa e estão relacionadas com os locais de alta concentração de matéria orgânica. As maiores concentrações de ferro estão dispostas majoritariamente no Rio Indaiá.

Palavras-Chave: Matéria orgânica, lago de Três Marias, Barragem da CEMIG, distribuição de granulometria

\section{ABSTRACT}

This investigation assesses the disposition of organic matter, iron and aluminum oxides, as well as the granulometric distribution in the bottom sediments at the Três Marias / MG dam. 40 samples were collected throughout the lake. The collected material was heated in an oven at $40{ }^{\circ} \mathrm{C}$ for 36 hours and then subjected to sieving. Iron and aluminum concentrations were determined by ICP OES. The organic matter content was obtained by the loss on ignition method. The results were compared with the values recommended by the sediment guide quality standard CONAMA No. 354/2012. In 7 samples the content of organic matter is above the legal limit. The sedimentary contribution from the São Francisco, São Vicente, Paraopeba, Extrema, Ribeirão do Boi, Borrachudo and Indaiá tributaries shows a general predominance of the deposition of sand-sized particles and a wide disparity in granulometry between the bottom sediments. The highest concentrations of aluminum were observed in the central-eastern portion of the dam and are related to places of high concentration of organic matter. The highest concentrations of iron are mainly disposed in the Indaiá River.

Keywords: Organic Matter; Três Marias lake; CEMIG Dam; Grain-size Distribution 


\section{INTRODUCTION}

It is a common knowledge in environmental analyses that bottom sediments are a natural receptor of pollutants and that their characteristics react directly to anthropogenic inputs. These sediments are geochemical reservoirs that trap and release elements according to the ecosystem properties. The biogeochemical cycles can incorporate potentially toxic elements from natural or anthropogenic sources to an aquatic dynamic of interactions, structuring a natural mechanism that disseminates pollutants during a possible remobilization of trace metals.

Sediments are complex and heterogeneous media and their role as a potential sink or source of contaminants is not yet fully understood (CHARRIAU et al., 2011). However, it is known that fine gran-size fraction on sediments concomitantly with the organic matter content and the oxi-hidroxides of iron $(\mathrm{Fe})$ and manganese $(\mathrm{Mn})$ are the main linkage phases for heavy metals on riverine sediments (USEPA, 2008; FAGNANI et al., 2011).

The construction of a dam modifies the natural dynamics of a river, interfering with the transport of solid particles. The new anthropogenic barrier works like a base level for the sedimentation from the tributaries load (CRUZ; RODRIGUES, 2013). Therefore, the physical characterization of the reservoir sediments has a paramount importance for understanding the new artificial environment and the modifications on ecosystemic interactions.

Many different kinds of land use and soil management can impact the aquatic systems around them. As Tong and Chen (2002) describe precisely, the surface runoff works as a carrier of particles and pollutants for lakes and reservoirs implying specificities on respective sediments.

The material deposited in the bottom of lacustrine environments is a direct result of a confluence between natural and active anthropogenic dynamics. In this process the granulometric distribution is determined by the original texture of the sedimentary sources and by the weathering, transport and deposition of the constituent particles (DINIS; CASTILHO, 2014). In each of these stages, the detrital body can interact with human and biological activities resulting in specificities and variations on the material within the same ecosystem.

The sedimentation processes in reservoirs (lakes) are mainly determined by surface runoff water that reaches the lake by the river channels (MARANESI, 2002; CRUZ; RODRIGUES, 2013). However, the granulometric and composition distribution of sediments in a basin is very variable along its longitudinal profile. It is caused by different lithogenic sources; by variation of vegetation cover; by the topographic context; by the rainfall regime and by the land use and soil occupation (HAAK; OLIVEIRA, 2012). Thus, delimiting the parameters of granulometry allows not only to infer local flow energy parameters, but also to attribute certain characteristics and susceptibilities to the environment.

The organic matter (OM) in aquatic systems may be present in dissolved form, in colloidal solution, and in suspension as organic detritus and living organisms. The biodegradation of organic matter promotes major changes in the redox conditions on the water-sediments interface, which could leads to a remobilization of trace metals to an aquatic system (CHARRIAU et al., 2011).

The linear relationship between $\mathrm{OM}$ and particle sizes is well described by Trask (1932). The two significant factors influencing the amount of OM in sediments are the input of organic matter into the basin and the detrital sedimentation rate, and not necessarily a direct reflection of the bioactivity in overlying lake column (HYNE, 1978).

The ability of adsorption of divalent cations by Iron $\left(\mathrm{Fe}^{2+}\right)$ and Aluminum $\left(\mathrm{Al}^{3+}\right)$ oxihidroxides on sediments suggest that that they play an important role in determination of other metals on bottom sediments in accordance with their inherent $\mathrm{Fe}$ and $\mathrm{Al}$ concentrations (KINNIBURGH et al., 1976).

The OM content, particle size distribution, oxide disposal and physical-chemical parameters have influence on sediment behavior concerning adsorption/desorption of metals, disposal of nutrients, geochemical stability and element supply for biomagnification and bioaccumulation processes (BORDOVSKIY 1965, CHANTIGNY, 2002, MASLENNIKOVA et al. 2012, TANSEL; RAFIUDDIN, 2016). 
Considering the parameters directly correlated to accumulation of trace elements, this study targets investigating of geochemical susceptibility of Três Marias reservoir focusing on the distribution of three

\section{STUDY AREA}

\subsection{HISTORICAL CONTEXT}

Inserted in the São Francisco basin, as shown in figure 1, the Três Marias lake, also known as "Doce Mar de Minas", was constructed in 1961 with the purpose of exploiting the local hydroelectrical potential. Therefore, this initiative significantly increased the local navigability and provided improvements for some economic segments as agriculture, livestock and tourism for local municipalities (OLIVEIRA, 2007).

The association of natural factors with the

\subsection{GENERAL SETTINGS}

On northwest of Minas Gerais state, the Três Marias lake (latitude: $18^{\circ}-21^{\circ} \mathrm{S}$, longitude: $43^{\circ} 30^{\prime}-46^{\circ} 40^{\prime} \mathrm{W}$ ) is located at the final part of Upper São Francisco River segment. This segment includes the basin from the source down to the city of Pirapora, comprising the sub-basins

\subsection{HYDROGRAPHY}

The hydrographic net that supplies the Três Marias lake has a drainage area of about 50,000 $\mathrm{km}^{2}$, and the altitude at the dam site is around $500 \mathrm{~m}$. The reservoir has a surface area of 1,050 $\mathrm{km}^{2}$ and a volume of $21 \times 10^{9} \mathrm{~m}^{3}$. The final installed capacity of the plant is $516,850 \mathrm{~kW}$ (OLIVEIRA, 2007). Rivers São Francisco, São Vicente, Paraopeba, Extrema, Ribeirão do Boi, Borrachudo and Indaiá stand out as the main

\subsection{GEOLOGY}

According to Almeida et al. (1977), Três Marias lake is immersed in the southern portion of the São Francisco Craton (CSF), an area that stabilized geotectonically at the end of the Transamazonian cycle (2.1 to $1.8 \mathrm{Gyr}$ ) working as the forefoot for the circumferential orogenic parameters: the organic matter content, the granulometric distribution and the disposal of oxi- hidroxides of iron and aluminum and their correlation with land use and soil management.

occupational model developed from the 1970s and 1980s, made the Três Marias reservoir gradually become an environment with peculiar characteristics. Consequently, the need for periodic studies increases, aiming the disposition and characterization of sediments in the area. (TRINDADE, 2010, HORN et al., 2014). Nowadays the Três Marias lake is under the management of Companhia Energética de Minas Gerais (CEMIG).

of Rio de Velhas, Paraopeba, Pará, Abaeté, Jequitaí, Indaiá and the Três Marias Dam on figure 1 (TRINDADE, 2010). The climate is typical tropical savanna type (Aw type, Köppen classification), characterized by dry winters and rainy summers (TORRES et al., 2019).

tributaries of the reservoir. These rivers are responsible for majority of the sediment loads (FONSECA et al., 2011).

The hypsometry of the influent basin exposed in figure 2 assigns a good part of the upstream flows in a terrain of high topographic disparity and to the south in a certain smoothness of relief at the mouth of the main tributaries.

bands (coming from Brasiliano). Stratigraphically the rocks of the investigated area belongs to Bambuí Group and Areado Group, both well explored on literature (CHIAVEGATTO, 1992; CAMPOS NETO et al., 2003; TRINDADE, 2010). 


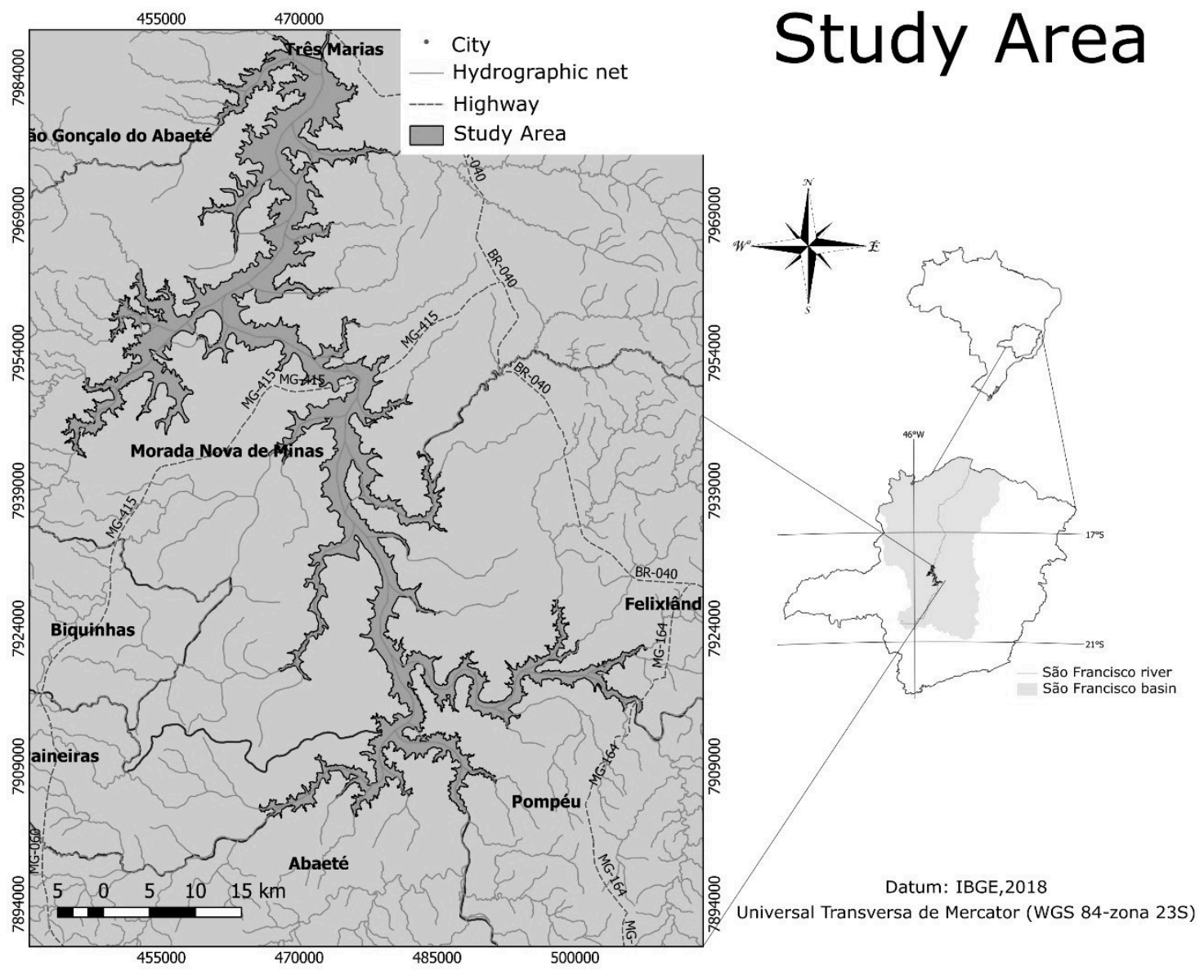

Figure 1:

Map of Três Marias Reservoir.



Figure 2 


\subsection{LAND USE AND SOIL MANAGEMENT}

According to the management plan published by the conservation unit of Pirapitinga ICMBIO (2013), the neighboring municipalities are distinguished by predominance of fishing at different levels and pisciculture farms at strategic spots, like the mouth of Paraopeba river and Boi stream.

The term "Pastures with soil management" refers to an area predominantly occupied by cultivated herbaceous vegetation. They are places formed by planting of perennial forages mostly destined to livestock. Areas occupied by endemic vegetation are "Natural Pasture", They are also used as livestock in a smaller scale and other activities with low anthropogenic interference (TEIXEIRA, 2018).

The land use and soil management are considered strong factor that controls the $\mathrm{OM}$ content in a ecosystem. In each type of

\section{MATERIAL AND METHODS}

\subsection{FIELD SAMPLING PROGRAMME}

Between $19^{\text {th }}$ at $21^{\text {th }}$ of July, sampling of 40 sediments samples was accomplished, following the recommendations of manual of soil analysis published by Empresa Brasileira de Pesquisa Agropecuária - EMBRAPA - (FILIZOLA, 2006).

Our sampling structure considered predominantly several site characteristics: the mouth of each tributaries; the conflux zones; the adjacent areas of expressive economical activities as piscicultures, livestock and agriculture, as illustrated on figure 3 . Due to the depth, it was not possible to sample sediments

\subsection{GRANULOMETRIC ANALYSIS}

The sediment granulometric properties were analyzed at the Geosciences Institute - Nucleus on Environmental Geochemistry Research (NGqA - CPMTC). Sediments were dried at 40 ${ }^{\circ} \mathrm{C}$ for 36 hours in an oven. To define particle sizes, all samples were softly grounded and management, the results interfere differently on the final soil/sediment composition (CHANTIGNY, 2003). Using Três Marias reservoir as an example, the concentration of organic matter is higher on environments with greater anthropogenic interference. In areas of pasture with land management or areas of agricultural activities, the alteration of the endemic vegetation and the soil management tend to intervene on the original pedogenic characteristics.

Still in the management plan, the predominance of intensive cattle breeding, the planting of corn, beans, coffee and soya are indicated. Additionally the silviculture characterized by Eucalyptus monoculture and charcoal production, like agriculture, are also known for the extensive use of stands out with the intense use of phytosanitary products.

from the center of the lake.

Parameters like turbidity, $\mathrm{pH}$, Eh, electrical conductivity and resistivity, dissolved oxygen, total dissolved solids and water temperature were measured in situ using a portable multiparameter water quality checker Hanna HI98194 and a portable turbidimeter Hanna HI93703.

Two kilograms of bottom sediments were collected and placed in a plastic container. To mitigate losses on the heavy metals content on the material, the sample were stored on a refrigerator at $4^{\circ} \mathrm{C}$ degrees.

conducted through a set of sieves (from 0.063 to $2 \mathrm{~mm}$ as displayed on table 1), according to NBR 7181/1988 (ABNT 1984) recommendations. For each sieve, the material retained was weighted and the percentage of each fraction calculated.

Table 1. Mesh specifications used on grain-size analysis.

\begin{tabular}{cccc}
\hline Classification & MESH(ABNT) & Grain size (mm) & MESH(TYLER) \\
\hline Gravel & 10 & 2 & 9 \\
Very coarse sand & 18 & 1 & 16 \\
Coarse sand & 35 & 0,5 & 32 \\
Médium sand & 60 & 0,250 & 60 \\
Fine senad & 120 & 0,125 & 115 \\
Very fine sand & 230 & 0,063 & 230 \\
Pelites & & $<0,063$ & \\
\hline
\end{tabular}




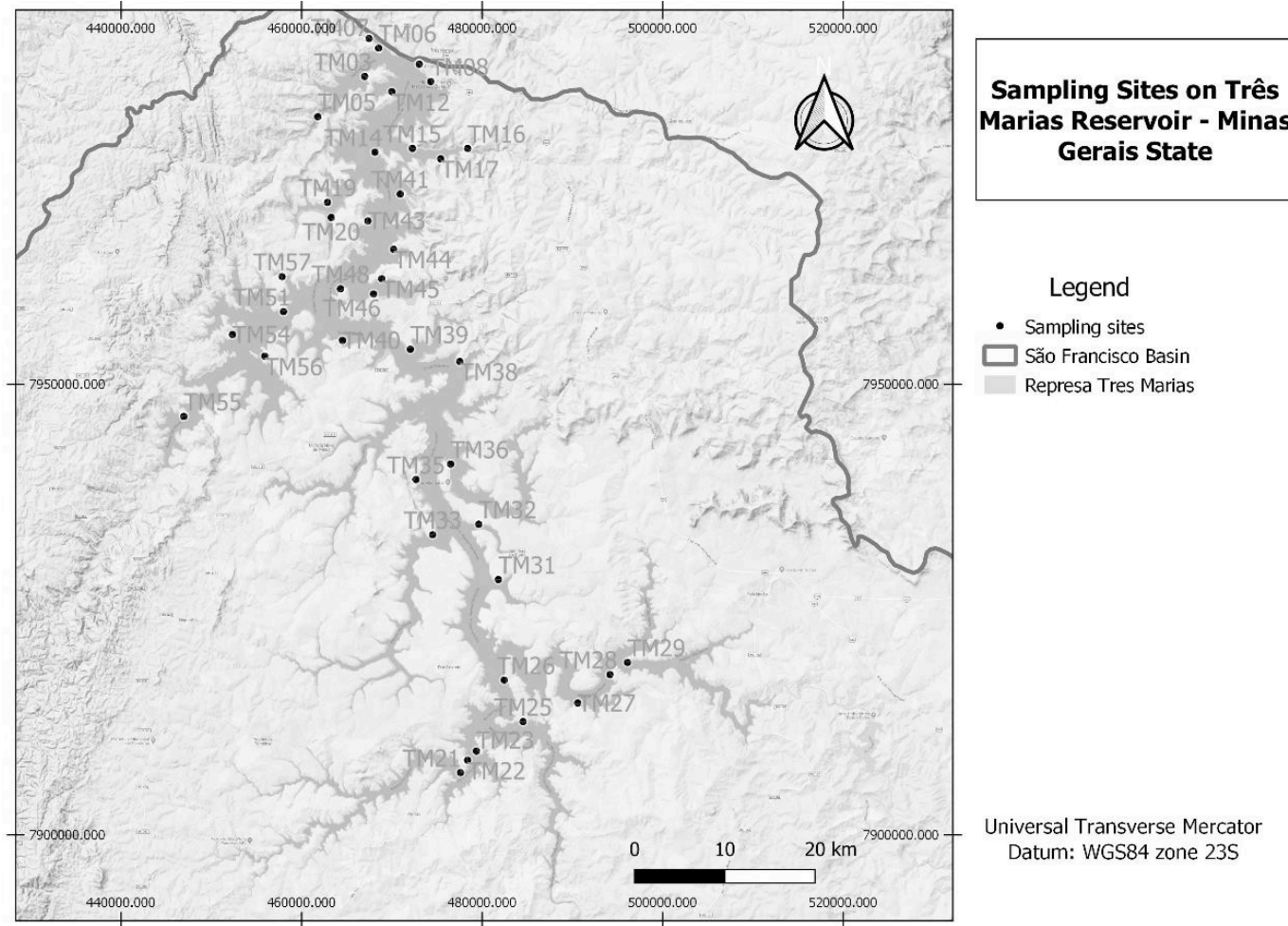

Figure 3

Sampling spots at the margin around Três Marias lake.

\subsection{ORGANIC MATTER ANALYSIS}

To quantify the organic matter on sampled bottom sediments we used the Loss-on-Ignition (LOI) method due to its rapid and reasonably accurate procedure for estimating the organic content. The procedure consists of submitting $0.5 \mathrm{~g}$ of the pelitic fraction (silt + clay) to heating at $105^{\circ} \mathrm{C}$ for two hours using a Muffle. Then recording the weight of the samples in a draftfree environment and repeating the procedure at a temperature of $550^{\circ} \mathrm{C}$ (DEAN, 1974; HEIRI et al., 2001). The LOI value expressed as percentage is defined by the equation below. Considering this procedure, we evaluate the percentage organic content in each of 40 samples

$$
\operatorname{LOI}(\%)=\frac{\left(\text { weight at } 105^{\circ} \mathrm{C}\right)-\left(\text { weight at } 550^{\circ} \mathrm{C}\right)}{\text { weight at } 105^{\circ} \mathrm{C}} X 100
$$

\subsection{CHEMICAL ANALYSIS}

The fine sediments $(<0.063 \mathrm{~mm})$ were subjected to acid digestion assisted by microwave (MARS - CEM) using a $10 \mathrm{~mL}$ concentrated nitric acid $\left(\mathrm{HNO}_{3}\right)$ on $0.5 \mathrm{~g}$ of sample in accordance to the method SW-846-3051 - US EPA (US EPA, 1998). The digested samples

\section{RESULTS AND DISCUSSION}

\subsection{ORGANIC MATTER DISTRIBUTION}

According to Brazilian legal norm CONAMA $\mathrm{n}^{\circ} 354 / 2012$, bottom sediments containing over $10 \%$ of OM could imply potential environmental disequilibrium, except for places naturally rich in organic matter. This last condition does not apply to the geological were analyzed by inductively coupled plasma optical emission spectroscopy (ICP OES) also at Nucleus on Environmental Geochemistry Research (NGqA - CPMTC) at Federal University of Minas Gerais. settings of Três Marias lake. As evidenced on table 2, 7 out of 40 samples analyzed for LOI presented concentrations that exceed the value established by current Brazilian legislation, reaching the maximum of $15.55 \%$ - sample TM 46. 
Table 2 - The OM in percentage content for each sample of Três Maria Reservoir. The highlighted samples has ratios not in compliance with the Brazilian legislation.

\begin{tabular}{cccccc}
\hline Sample ID & OM(\%) & Sample ID & OM(\%) & Sample ID & OM(\%) \\
\hline TM 01 & 4.72 & TM 22 & 5.96 & TM 40 & 4.80 \\
TM 03 & 5.38 & TM 23 & 5.12 & TM 41 & 4.73 \\
TM 05 & 4.91 & TM 25 & 5.15 & TM 43 & 0.46 \\
TM 06 & 6.08 & TM 26 & 5.12 & TM 44 & 8.91 \\
TM 07 & 5.99 & TM 27 & 4.09 & TM 45 & 7.09 \\
TM 08A & 3.29 & TM 28 & $\mathbf{1 4 . 4 7}$ & TM 46 & $\mathbf{1 5 . 5 5}$ \\
TM 12 & 6.62 & TM 29 & 6.53 & TM 48 & $\mathbf{1 3 . 2 2}$ \\
TM 14 & 6.45 & TM 31 & $\mathbf{1 2 . 7 0}$ & TM 51 & 7.74 \\
TM 15 & 4.67 & TM 32 & $\mathbf{1 4 . 5 7}$ & TM 54A & 6.32 \\
TM 16 & 4.87 & TM 33 & 8.01 & TM 55 & 7.10 \\
TM 17 & 5.07 & TM 35 & 8.47 & TM 56 & 6.36 \\
TM 19 & 8.56 & TM 36 & $\mathbf{1 4 . 1 7}$ & TM 57 & 7.85 \\
TM 20 & 7.93 & TM 38 & 2.13 & & \\
TM 21 & 8.63 & TM 39 & $\mathbf{1 3 . 7 2}$ & &
\end{tabular}

By comparing sampling sites (conditions and locations) with land use and soil management map produced by Brazilian Geography and Statistics Institute (IBGE), it becomes possible to correlate spatially the organic matter concentration with the natural/anthropogenic pedogenetic settings around the lake, as displayed on figure 4.

The reservoir shores are predominantly occupied by areas of natural pastures, silviculture and pasture land with soil management. Observing figure 4, samples with high percentages of organic matter (TM36; TM38; TM46; TM48) are correlated with agriculture areas. Samples TM31 and TM32 are associated with pasture areas with soil management and one sample (TM28) are close to natural pasture areas. Once the natural settings changes by human interference, the surface

\subsection{GRANULOMETRY AND SEDIMENT SUPPLY}

The arrangement of sampled sites is on evidence at figure 5. For each analyte, we have a chart to ilustrate individually the granulometric composition, showing a wide range of particles predominance on Três Marias reservoir.

Analyzing the main tributaries separately as indicated in table 2, it becomes possible to identify the contribution of each river for the overall sedimentary supply on the reservoir. The Indaiá River presents wider variability in the percentage of coarse grained particles (gravels) and the second larger amplitude inherent to the clay content. This river flows through areas of relative homogeneity as to the type of land use and occupation with predominance of natural pastures. According to the hypsometric map in runoff carries the organic particles more effectively to the lake system, which could explain the high ratios of organic matter on TM36, TM39, TM46 and TM48. In contrast, the lower ratios of OM content in the sediments of the lake appear to be correlated mainly with silviculture and natural pasture areas. According to Peixoto et al. (2018) the silviculture practice operates as a strong mechanism to reduce significantly the input and transport of organic matter to adjacent aquatic systems. As an exception, TM28 has a high ratio of organic matter even being closer to a natural pasture area. However, on a field investigation, we notice that this sampling site is spotted on a downstream of a pisciculture farm, which could imply in a higher OM content due to a high bioproductivity adjacent area.

figure 2, the Indaiá flows on areas with greater altimetric disparity and it passes over long distances when compared to the other tributaries.

The Ribeirão do Boi River deposits the largest fine sediment (pellets) supply on the lake, as exposed on table 2. These tributaries run through less rugged places and with the predominance of natural pastures and pastures with soil management.

In a regional context, the dam shows certain homogeneity and predominance of the sand fraction as the main load of the river flows. The existing variations, however, can imply in energetic variations of the watercourse, inherent characteristics of the sedimentary source by itself 


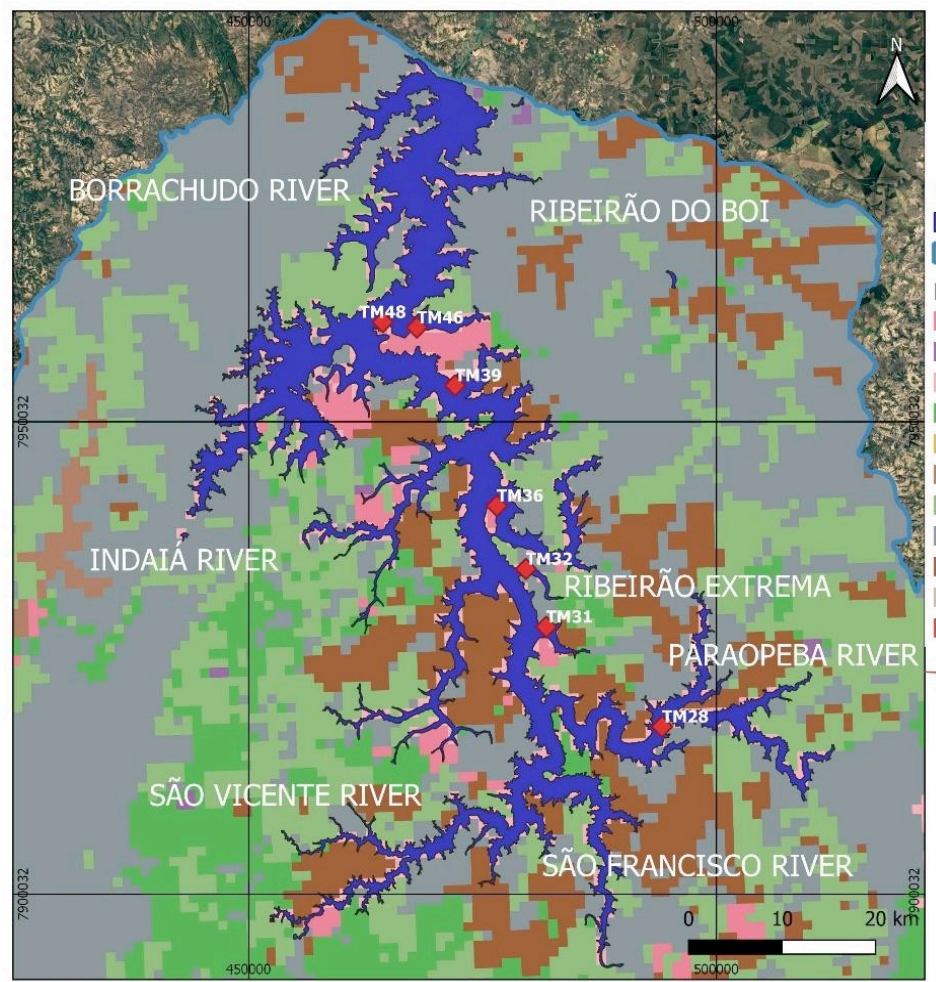

\section{LAND USE AND SOIL \\ MANAGEMENT MAP OF TRÊS MARIAS RESERVOIR - MINAS GERAIS STATE} LEGEND

Organic Matter over $10 \%$ on samples Watershed $\square$ São Francisco basin Land Use and Soil Management Agriculture Activities Anthropogenic Surface Flood surface

Agriculture with Remaining Grassland Vegetatio Agriculture with Remaining Native Forest Native Forest with Agriculture Practices Pastures with Soil Management Natural Pastures Forestry Grassland Vegetation Native Forest management map (IBGE, 2018).

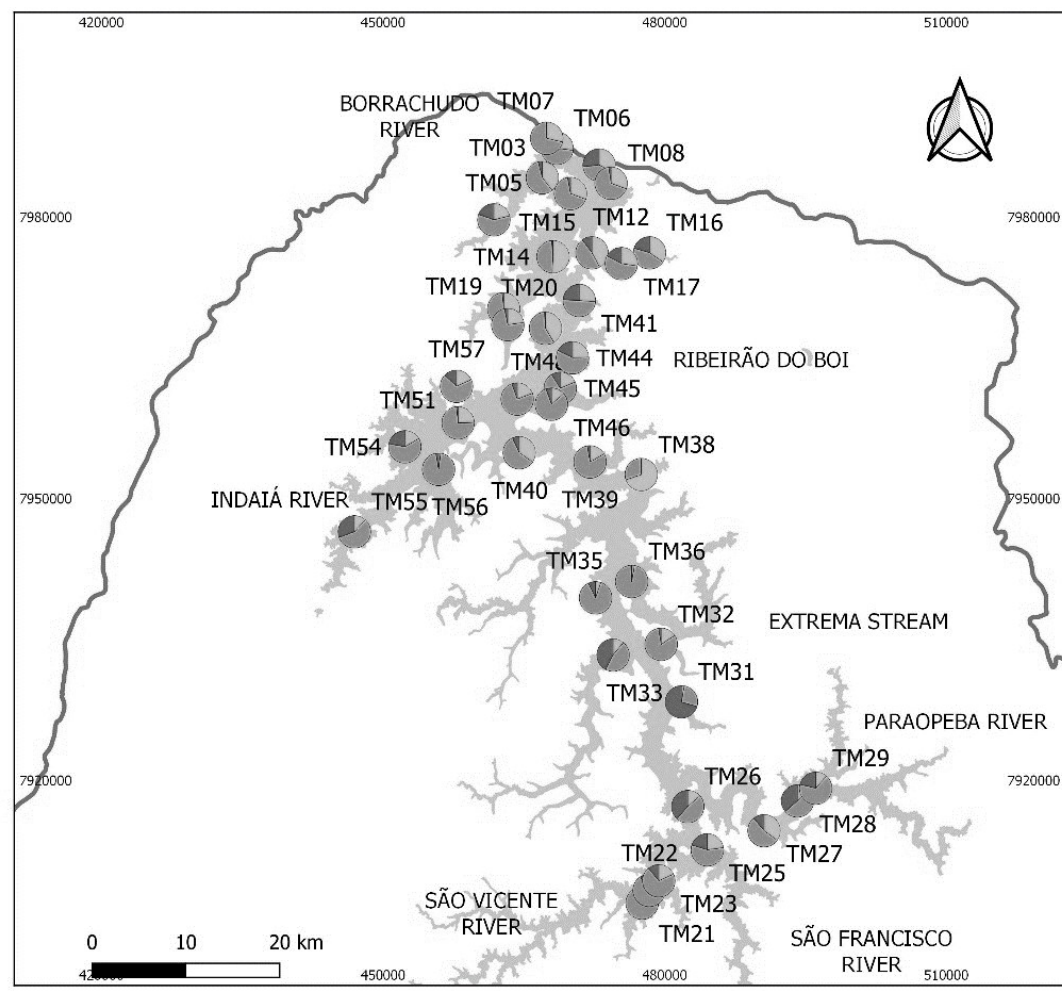

GRANULOMETRIC

DISPOSITION ON TRÊS MARIAS LAKE MINAS GERAIS STATE 
Table 3. Range of grain-sizes (\%) in the main tributaries

\begin{tabular}{lccc}
\hline Location (river/stream) & Gravel range & Sande range & Pelite range \\
\hline Borrachudo & $0.34-21.54$ & $64.50-77.68$ & $23.00-48.57$ \\
Ribeirão do Boi & $12.68-24.34$ & $53.40-61.04$ & $30.31-50.90$ \\
Indaiá & $1.86-32.64$ & $61.01-96.46$ & $1.95-27.28$ \\
Extrema & $0.90-2.98$ & $89.08-97.76$ & $2.73-17.43$ \\
Paraopeba & $12.24-38.67$ & $54.34-70.15$ & $12.77-38.40$ \\
São Vicente & $4.79-11.77$ & $75.08-88.01$ & $19.30-25.25$ \\
São Francisco & $21.07-41.77$ & $50.51-60.54$ & $14.70-24.47$ \\
\hline
\end{tabular}

\subsection{OXIDE DISPOSITION}

\subsubsection{ALUMINUM}

Using the QGIS 3.6, the interpolation of $\mathrm{Al}$ analytical data was carried out using Inverse Distance Weighting (IDW) as shown on Figure 6. The bright colors imply in higher concentrations of Aluminum on the lake. Higher concentrations of $\mathrm{Al}$ are observed on the centraleast area of the lake. As discussed earlier, sediments with elevated aluminum content are more susceptible to trap potential toxic elements on its structure. A comparison between aluminum and organic matter results shows an interesting spatial correlation existent in both parameters. The concomitance of $\mathrm{Al}$ and $\mathrm{OM}$ lead us to a two major hypotheses:

1. The concentration of those variables are a direct consequence of the weathering/erosion and surface runoff transportation to the reservoir that could be intensified by the Land Use and Soil Management (mainly agriculture practices).

2. The previous high ratios of Organic Matter works as a mechanism to adsorb/trap more aluminum to the sediment structure, implying in a further high concentration of $\mathrm{Al}$ on circled areas.

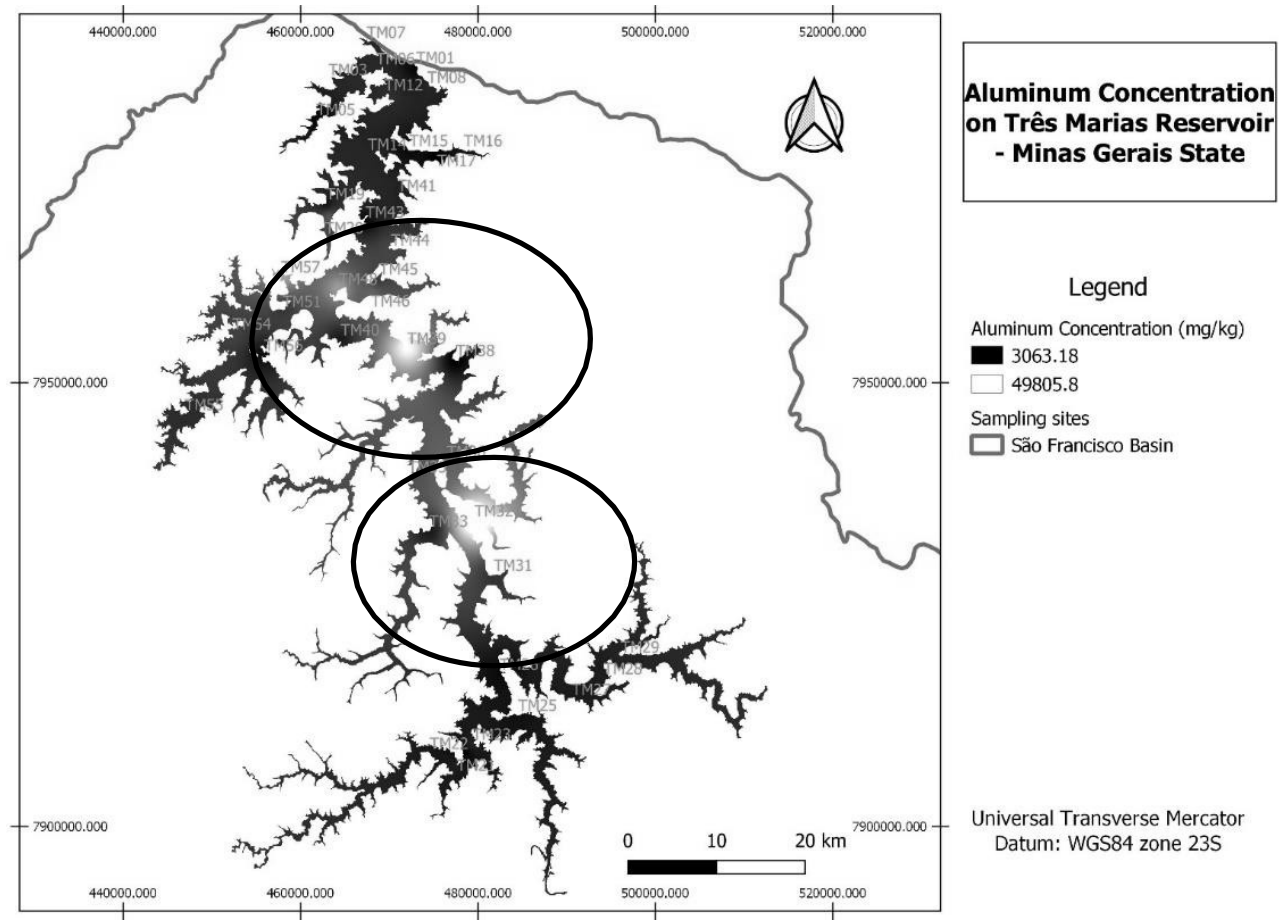

Figure 6 Aluminum compound disposition on Três Marias lake. The circled areas shows higher concentrations in the reservoir 


\subsubsection{IRON}

Also using IDW on QGIS 3.6, the interpolation of Fe data are displayed on figure 7. The bright colors imply in higher concentrations of iron on the lake. The higher concentration of iron is on Rio Indaiá at northwest of the reservoir.
No clear pattern was established of Iron concentration for this tributary. The Rio Indaiá flows through a sedimentary substrate and we did not identify an anthropogenic practice that could explain this anomalous behavior.
Iron

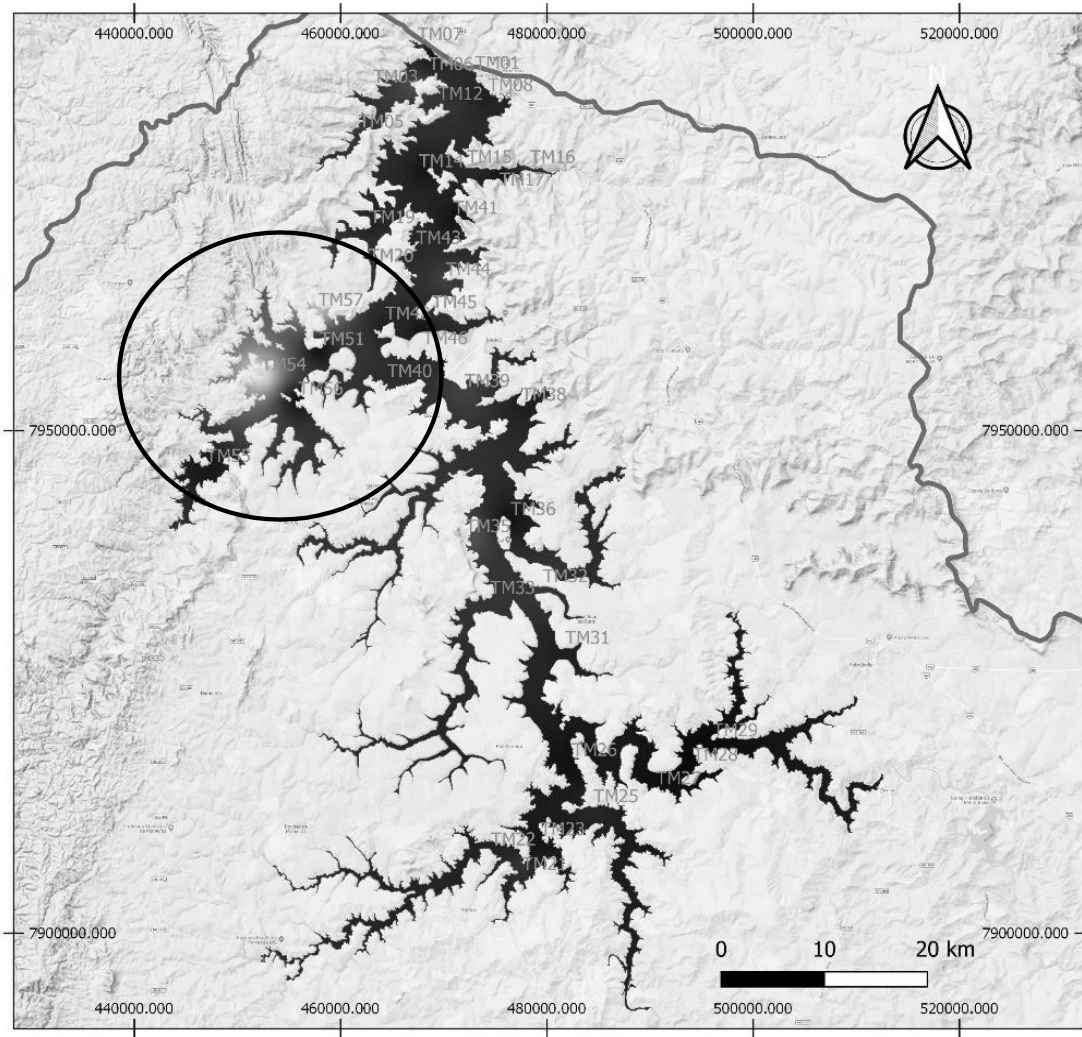

disposition in sediment samples from Três Marias Lake. Those circled areas shows the higher

\section{Iron Concentration on Três Marias Reservoir - Minas Gerais State}

\section{Três Marias reservoir Iron Concentration $(\mathrm{mg} / \mathrm{kg})$ 3869.62 51047.4 $\square$ São Francisco Basin}

Universal Transverse Mercator Datum: WGS84 zone 23S

Figure 7

\section{CONCLUSIONS}

The lake presents heterogeneous distribution on organic matter rates and its dispersion can be correlated to the various types of land use and soil management along the lakeshores. $17.5 \%$ of sampled sites analyzed have overpassed the ratios recommended by CONAMA norm 354/2012, which may imply on environmental risks. The anthropogenic modification on the terrain increases the susceptibility to erosive and leaching phenomena, enabling an intensification of transferences process of $\mathrm{OM}$ and oxides from the continental system to lacustrine zones. Close to the agriculture area, the central-east margin shows higher ratios of organic matter and aluminum, which could imply in a most affected zone in Três Marias lake. In an overall evaluation, Três Marias lake presents a wide range of particles around the lake and a general predominance of sand supply. Indaiá River has the largest load of coarse-particles fraction. On the other hand the Ribeirão do Boi carries the most significantly pellet supply to the system. This investigation established a spatial analysis referring to the dry season of the reservoir (winter). It is interesting to evaluate the same parameters in other season to understand the geochemical behavior under different conditions. A future comparison of $\mathrm{OM}$ behavior along the time and correlated with the land use/soil management changes could bring a better interpretation of the $\mathrm{OM}$ dynamics on this system. 


\section{ACKNOWLEDGEMENTS}

The authors gratefully thank the ICMBio Pirapitinga Uni for the logistical support, the Núcleo de Geoquímica Ambiental (NGqA UFMG) and the Laboratório de Geoquímica

\section{REFERENCES}

ABNT - Associação Brasileira de Normas Técnicas. NBR 7181: Solo - Análise Granulométrica (Método de Ensaio). Rio de Janeiro, 13 p. 1984

ALMEIDA, F.F.M. O Cráton do São Francisco. Revista Brasileira de Geociências, 7, 285-295, 1977.

BORDOVSKIY, O. K. Accumulation of organic matter in bottom sediments. Marine Geology, 3(1-2), 33- 82, 1965.

CAMPOS NETO, M. C.; PEDROSA SOARES, A. C.; NOCE, C. M.; ALKMIM, F. F.; EBERT, H. Mapa Geológico do Estado de Minas Gerais. Belo Horizonte: CPRM, escala 1:1.000 000, 2003.

CHANTIGNY, M. H. Dissolved and waterextractable organic matter in soils: a review on the influence of land use and management practices. Geoderma, 113(3-4), 357-380, 2002.

CHARRIAU, A.; LESVEN, L.; GAO, Y.; LEERMAKERS, M.; BAEYENS, W.; OUDDANE, B.; BILLON, G. Trace metal behaviour in riverine sediments: Role of organic matter and sulfides: Applied Geochemistry, 26(1), 80-90, 2011.

CHIAVEGATTO, J. R. S. Análise estratigráfica das seqüências tempestísticas da Formação Três Marias (Proterozóico Superior), na porção meridional da Bacia do São Francisco. 1992. Dissertação de Mestrado, Departamento de Geologia, Escola de Minas, Universidade Federal de Ouro Preto, $216 \mathrm{p}$.

CONAMA 354/2012. Conselho Nacional do Meio Ambiente. Resolução/CONAMA/n. ${ }^{\circ} 354$ DE 2012.

CRUZ, L. M.; RODRIGUES, S. C. Avaliação do potencial de produção de sedimentos para a PCH Piedade Monte Alegre de Minas/MG, Caminhos de Geografia, 14(47), 54-73, 2013

DEAN, W. E. Determination of carbonate and organic matter in calcareous sediments and sedimentary rocks by loss on ignition: comparison with other methods. Journal of Sedimentary Petrology, 44(1), 242-248, 1974.

DINIS, P.; CASTILHO, A. M. Assinatura granulométrica como indicador da proveniência: potencialidades e limitações.. In
Ambiental (LGA- UFVJM) for the laboratorial assistance and the Brazilian agency Coordenação de Aperfeiçoamento do Pessoal de Nível Superior (CAPES) for financial support.

Dinis, P.; Gomes, A.; Monteiro Rodrigues, S. (Eds) Proveniência de materiais geológicos: abordagens sobre o Quaternário de Portugal, 118,2014

FAGNANI, E.; GUIMARÃES, J. R.; MOZETO, A. A; FADINI, P. S.. Sulfetos volatilizáveis por acidificação e metais extraídos simultaneamente na avaliação de sedimentos de água doce. Química Nova, 34(9), 1618-1628, 2011

FONSECA, R.; PATINHA, C.; BARRIGA, F.; M. MORAIS, M.. Geochemistry of metals in the bottom sediments of tropical dam reservoirs in San Francisco River (Três Marias, MG) and Tocantins River (Tucuruí, PA), Brazil In: International Water Association, Proceedings of Specialized Conference on Watershed \& River Basin Management: p. 8. 2011

HAAK, L.; OLIVEIRA, F. A. Caracterização granulométrica de sedimentos de fundo na bacia hidrográfica do Rio Cubatão do Norte, SC. In: IX SINAGEO, Rio de Janeiro. 2012

HEIRI, O.; LOTTER, A. F.; LEMCKE, G. Loss on ignition as a method for estimating organic and carbonate content in sediments : reproducibility and comparability of results: Journal of Paleolimnology, 25(1),101-110, 2001

HORN, A. H., BAGGIO, H., SCHIMITH, R. S. Selected element distribution in bottom sediment samples from Três Marias Lake and its significance, Minas Gerais, Brazil. Romenian Journal of Mineral Deposits. 87, 39-42, 2014

HYNE, N. J. The distribution and source of organic matter in reservoir sediments. Environmental Geology, 2(5), 279-287, 1978

IBGE - Instituto Brasileiro de Geografia e Estatística. Monitoramento da Cobertura e Uso da Terra do Brasil 2014-2016: Rio de Janeiro, 29 p, 2018

ICMBIO/MMA - Instituto Chico Mendes de Conservação da Biodiversidade/Ministério do Meio Ambiente. Plano de Manejo - Estação Ecológica de Ipirapitinga. Brasilia. 2013.

KINNIBURGH, D. G.; JACKSON, M. L. SYERS. J. K. Adsorption of Alkaline Earth Transition, and Heavy Metal Cations by Hydrous Oxide Gels of Iron and Aluminium 40(5), 796-799, 1976. 
MARANESI, D. A. Avaliação Geoambiental em Áreas de Cerrado no Triângulo Mineiro para Implantação de Pequenos Reservatórios Superficiais de Água: Aplicação na Folha de Tupaciguara, MG (1:100.000). 2002. 141 p. Tese - Instituto de Geociências e Ciências Exatas ,Universidade Estadual Paulista, Rio Claro. 2002

MASLENNIKOVA, S.; LARINA, N.; LARIN, S. The effect of sediment grain size on heavy metal content. Lakes Reservoirs and Ponds, 6(1), 43-54, 2012

OLIVEIRA, M. R.. Investigação da contaminação por metais pesados da água e do sedimento de corrente nas margens do Rio São Francisco e tributários, a jusante da represa da CEMIG, no município de Três Marias, Minas Gerais. 2007. 150 p. Tese. Instituto de Geociências, Universidade Federal de Minas Gerais, 149 p. 2007

PEIXOTO, S. S. J.; AMARAL, P. H. M.; GUIMARÃES L. P.; ROCHA, C. H. B.; ALVES, R. G.. Caracterização granulométrica do sedimento de nascentes de sub-bacias do rio paraíba do sul em áreas plantadas com eucalipto. In: III Simpósio de Recursos Hídricos do Rio Paraíba do Sul. 2018

TANSEL, B.; RAFIUDDIN, S. Heavy metal content in relation to particle size and organic content of surficial sediments in Miami River and transport potential. International Journal of Sediment Research, 31(4), 324-329, 2016
TEIXEIRA, P. C.; DONAGEMMA, G. K.; FONTANA, A. W.; TEIXEIRA, G. Manual de métodos de análise de solo: Brasília, Embrapa, 573 p. 2017

TEIXEIRA, G. 2018. IBGE: As mudanças na cobertura e uso da terra no Brasil. Disponível em:< https://www.brasildefato.com.br/2017/01/04/ibg e-as-mudancas-na-cobertura-e-uso-da-terra-nobrasil/>. Acesso em 04 de nov. 2018.

TONG, S. T. Y.; CHEN, W. Modeling the relationship between land use and surface water quality. Journal of Environmental Management, 66(4), 377-393, 2002

TORRES, I. C.; HORN, A. H.; LEMOS, R. S. Metal dynamics in a tropical watershed: The São Francisco river and its compartments: Geochimica Brasiliensis, 33(2), 221-233, 2019.

TRASK PARKER, D.; HAMER, H. E.; WU, C C. Origin and environment of source sediments of petroleum. Gulf Publishing Company. Houston, Texas. 323 p. 1932

TRINDADE, W. M. Concentração e distribuição de metais pesados em sedimentos do Rio São Francisco entre Três Marias e Pirapora/MG: fatores naturais e antrópicos. 2010. $111 \mathrm{p}$. UFMG. Belo Horizonte. Dissertação. 2010.

USEPA. Procedures for the Derivation of Equilibrium Partitioning Sediment Benchmarks (ESBS) for the Protection of Benthic Organisms: Compendium of Tier 2 Values for Nonionic Organics. EPA/600/R-02/016 PB2008-107282. US Environmental Protection Agency. Duluth, MN. 75 p. 2008 